Article

\title{
Cross-Sectional Study to Evaluate Knowledge on Hand Hygiene in a Pandemic Context with SARS-CoV-2
}

\author{
Cătălina Iulia Săveanu ${ }^{1}$, Andreea Porsega ${ }^{2}$, Daniela Anistoroaei ${ }^{1, *}$, Cristina Iordache ${ }^{3, *}$, Livia Bobu $^{1, * \mathbb{D}}$ \\ and Alexandra Ecaterina Săveanu ${ }^{2}$
}

check for

updates

Citation: Săveanu, C.I.; Porsega, A.; Anistoroaei, D.; Iordache, C.; Bobu, L.; Săveanu, A.E. Cross-Sectional Study to Evaluate Knowledge on Hand Hygiene in a Pandemic Context with SARS-CoV-2. Medicina 2022, 58, 304. https://doi.org/ 10.3390/medicina58020304

Academic Editor:

Rafael Delgado-Ruiz

Received: 23 December 2021

Accepted: 15 February 2022

Published: 17 February 2022

Publisher's Note: MDPI stays neutral with regard to jurisdictional claims in published maps and institutional affiliations.

Copyright: (C) 2022 by the authors. Licensee MDPI, Basel, Switzerland. This article is an open access article distributed under the terms and conditions of the Creative Commons Attribution (CC BY) license (https:// creativecommons.org/licenses/by/ $4.0 /)$.
1 Department I-Surgicals, Faculty of Dental Medicine, University of Medicine and Pharmacy Grigore T Popa 700115 Iasi, Romania; cisaveanu@prevod.umfiasi.ro

2 Faculty of Dental Medicine, University of Medicine and Pharmacy Grigore T Popa, 700115 Iasi, Romania; andreeapor@yahoo.com (A.P.); alexandrasaveanu@yahoo.com (A.E.S.)

3 Department of Implantology, Removable Prostheses, Dental Technology, Faculty of Dental Medicine, University of Medicine and Pharmacy, 700115 Iasi, Romania

* Correspondence: daniela.anistoroaei@umfiasi.ro or cmiortodent@yahoo.com (D.A.); ccmiiordache@yahoo.com (C.I.); livia12bo@gmail.com or livia12mi@yahoo.com (L.B.); Tel.: +4-0721-377-269 (D.A.); +4-0745-503-852 (C.I.); +4-0747-896-205 (L.B.)

\begin{abstract}
Background and Objectives: The basis of any infection control program is hand hygiene (HH). The aim of this study was to investigate knowledge of $\mathrm{HH}$ among medical students. Materials and Methods: Students were randomly selected from two Romanian universities and a cross-sectional, questionnaire-based study was conducted between January and May 2021. The answers regarding demographic data and knowledge concerning the methods, the time and the antiseptics used for $\mathrm{HH}$ were collected. The selection of the study group was made according to selection criteria in accordance with ethical issues. A descriptive statistical analysis was performed, and a chi-square test was used for data comparison, with a cut-off point of 0.05 for statistical significance. Results: The results indicated that the attitude of the students towards the practice of $\mathrm{HH}$ improved significantly. Most students believe that simple HH can control infections. Significant differences were found by the year of study in terms of the hand surfaces included and recommended duration $(p<0.05)$. Conclusions: In conclusion, the study shows that most respondents have sufficient knowledge on $\mathrm{HH}$, meaning that a higher compliance is required to control infections. The indicated reasons of non-compliance with $\mathrm{HH}$ are emergencies and other priorities.
\end{abstract}

Keywords: hand hygiene; antiseptic solution; decontamination

\section{Introduction}

Infection control in dentistry is a broad concept on several levels. The increase in the incidence of certain diseases, including SARS-CoV-2 infection, is also linked to the lack of compliance of medical staff on various issues. Hand hygiene $(\mathrm{HH})$ is the basis of any program for infection control [1-6]. However, the promotion of hand hygiene behavior remains a complex issue $[3,7,8]$. Task forces for discussion and expert consensus on critical issues related to hand hygiene in health care are based on behavioral changes, education, training, tools, World Health Organization (WHO)-recommended hand antisepsis formulations, glove use, water quality for handwashing, patient involvement, religious and cultural aspects of hand hygiene, indicators for service implementation and monitoring, regulation and accreditation, communication/campaigning, and national guidelines on hand hygiene [9]. Hand hygiene is a good predictor of nosocomial infections, especially when the medical staff come in contact with a patient's oral cavity [10]. HH is a widespread topic among students or practitioners. Aspects regarding $\mathrm{HH}$ have been addressed in numerous studies conducted during the pandemic period with SARS-CoV-2 [11-13]. 
Wearing gloves does not provide absolute protection and, therefore, $\mathrm{HH}$ takes on extra value. The dynamics of hand contamination are similar on gloved versus ungloved hands; gloves reduce hand contamination, but do not fully protect from the acquisition of bacteria during patient care. Therefore, the glove surface is contaminated, making possible cross-transmission through contaminated gloved hands [9]. The WHO stated "The five moments for hand hygiene", namely: before contact with the patient, before performing any procedure, after exposure to biological fluids at risk, after contact with the patient, and after contact with objects around the patient [9].

The methods of $\mathrm{HH}$ are: simple washing with soap and water, washing with water and antiseptic soap, rubbing the hands with antiseptic solution (60-95\% alcohol) and surgical washing.

$\mathrm{HH}$ with soap and water promotes the mechanical removal of organic matter, visible dirt and microorganisms from the skin surface [9]. Transient flora (transient microbiota), which colonizes the superficial layers of the skin, is more amenable to removal by routine $\mathrm{HH}$. Transient microorganisms do not usually multiply on the skin, but they survive and sporadically multiply on the skin surface $[9,14,15]$. Normal human skin is colonized by bacteria, with total aerobic bacterial counts ranging from more than 1 to $1 \times 10 \mathrm{CFU} / \mathrm{cm}^{2}$ on the forearm $[9,16]$.

$\mathrm{HH}$ is considered by some researchers to be more effective than decontamination with antiseptic solutions, as it reduces the microbial load by eliminating transient flora and organic matter [17]. Other studies have shown that washing with soap and water for $30 \mathrm{~s}$ leads to the elimination of noroviruses from the hands [18] and an increase of the washing time decreases the number of microorganisms on hand surfaces [19].

$\mathrm{HH}$ with antiseptic solution is increasingly used, due to its easy and fast application, and proven efficiency; it reduces transient flora and resident flora, but not organic matter [9]. WHO recommends alcohol-based hand rubs based on the following: evidence-based, fast-acting and broad-spectrum microbicidal activity with a minimal risk of generating resistance to antimicrobial agents; suitability for use in resource-limited or remote areas with lack of accessibility to sinks or other facilities for hand hygiene; and capacity to promote improved compliance with hand hygiene by making the process faster and more convenient [9]. The effectiveness of $\mathrm{HH}$ with antiseptic solution depends on the type of alcohol (the most commonly used are chlorhexidine gluconate, iodophors and triclosan), the amount applied (usually $3 \mathrm{~mL}$ ) and the technique used [20]. The Center for Disease Control and Prevention (CDC) published in 2020 the Guideline for HH in HealthCare Settings, an update of the guide developed in 2002 [2]. According to the Guideline, in all the cases of contact with the patient, HH with antiseptic solution is recommended, instead of the traditional method of simple $\mathrm{HH}$ (unless the hands are visibly dirty) [21].

A lot of information is available regarding $\mathrm{HH}$. However, it is not very well known, or not properly applied, and this is why the pathogenic microbial flora of the hands is still involved in the transmission of diseases. Numerous studies have highlighted gaps in hand hygiene behaviors [22-24]. Because dental clinical activity involves the direct contact of medical staff with biological fluids, $\mathrm{HH}$ is very important and must be fully known by all future practitioners. In this context, university education aims to build the professional behavior of future specialists.

The aim of the present study was to investigate knowledge about $\mathrm{HH}$ practices among students attending two medical universities in Romania.

The null hypothesis was that there are no differences in knowledge about $\mathrm{HH}$, regardless of the educational institution and the year of study.

The testable hypothesis was that there are differences in knowledge about $\mathrm{HH}$, depending on the educational institution and the year of study. This research was used to identify gaps in knowledge, attitude toward and practices of hand hygiene among university students. The results of this study are very useful to motivate the implementation of behavior change programs on measures to induce proper hand hygiene. 


\section{Materials and Methods}

The questionnaire method was used for the assessment of students' level of knowledge.

\subsection{The Survey}

A cross-sectional, questionnaire-based study was conducted between January and May 2021. The 51-item questionnaire used was evaluated by a panel of experts from the Faculty of Dentistry within the "Grigore T. Popa" University of Medicine and Pharmacy in Iasi, Romania, following a qualitative pre-testing of the content and validation. The questionnaire was openly applied and it was uploaded online on the Google docs platform. The 51 items referred to: demographic data (Q1-Q4); data on the frequency of $\mathrm{HH}$ in relation to the patient and other situations, and on the use of $\mathrm{HH}$ products (Q5-Q15); data regarding infection control by simple hand decontamination, and the substances used (Q16-Q34); data regarding infection control by surgical decontamination (Q35-Q42); and data regarding the antiseptic substances for $\mathrm{HH}$ (Q43-Q51).

\subsection{The Study Group}

The study included students randomly selected from two universities: "Grigore T. Popa" University of Medicine and Pharmacy in Iasi (UMP1) and "George Emil Palade" University of Medicine, Pharmacy, Science and Technology in Targu Mures (UMP 2) Table 1. The selection of the study group was made following selection criteria in accordance with ethical issues and good practices of study. The inclusion criteria were: students enrolled in a form of education with a medical profile; students who consented to participate in the study; students who agreed to fill in the questionnaire; students attending years 3 to 6. The exclusion criteria were: students who did not attend a university with a medical profile; students in the first and second years of study, as they did not go through the preparation module regarding infection control. Sampling of the respondents was unlikely. The students considered eligible were those who agreed to complete the questionnaire after reading its content. A total of 126 subjects completed the questionnaire.

Table 1. General characteristics of the study group.

\begin{tabular}{|c|c|c|c|c|c|c|c|c|}
\hline & \multirow{3}{*}{ Q } & & \multicolumn{4}{|c|}{ Year of Study } & \multicolumn{2}{|c|}{ Total } \\
\hline & & & 3 rd & 4th & 5 th & 6th & & \\
\hline & & & $N$ & $N$ & $N$ & $N$ & $N$ & $\%$ \\
\hline \multirow{3}{*}{ Q1 } & \multirow{3}{*}{ Gender } & Total & 29 & 31 & 18 & 48 & 126 & 100 \\
\hline & & Male & 6 & 9 & 7 & 10 & 32 & 25.4 \\
\hline & & Female & 23 & 22 & 11 & 38 & 94 & 74.6 \\
\hline \multirow{2}{*}{ Q2 } & \multirow[b]{2}{*}{ Area } & Rural & 13 & 10 & 11 & 15 & 49 & 38.9 \\
\hline & & Urban & 16 & 21 & 7 & 33 & 77 & 61.1 \\
\hline \multirow{2}{*}{ Q3 } & \multirow{2}{*}{ University } & UMP1 & 26 & 3 & 10 & 43 & 82 & 65.1 \\
\hline & & UMP2 & 3 & 28 & 8 & 5 & 44 & 34.9 \\
\hline \multirow{2}{*}{ Q4 } & \multirow{2}{*}{ Specialization } & Dental Medicine & 26 & 7 & 8 & 26 & 67 & 53.2 \\
\hline & & General Medicine & 3 & 24 & 10 & 22 & 59 & 46.8 \\
\hline
\end{tabular}

\subsection{Data Collection}

For the data collection, the following closed-ended or variable-answer questions were applied as follows: The data were collected and introduced into a database. SPSS 26.00 for Windows (IBM, Armonk, NY, USA) was used for the processing of statistical data. A descriptive statistic of the study was performed by applying crosstabs to all the aspects analyzed according to MS and $\mathrm{HH}$. The Chi-square test was used for data comparison. The cut-off point of statistical significance $p$ was set at 0.05 . 


\section{Results}

The mean age of the students was 23.15 years $( \pm 2.083)$, with the youngest being 19 years old and the eldest being 37 years old. The general characteristics of the study group are presented in (Table 1).

Attitude regarding $\mathrm{HH}$ before and during the SARS-CoV-2 pandemic indicated that $\mathrm{HH}$ was performed by $42.9 \%$ of the students more than 10 times a day during the pandemic, compared to $10 \%$ before its onset. Statistically significant differences were found only by the year of study $(p<0.05)$ (Table 2$)$, with students in the 6th year performing $\mathrm{HH}$ more frequently.

Table 2. Frequency of answers to questions concerning hand hygiene $(\mathrm{HH})$ in relation to the patient and other situations and the use of $\mathrm{HH}$ products. Results of statistical significance tests comparing the frequency of $\mathrm{HH}$ in relation to the patient and the use of $\mathrm{HH}$ products by variables.

\begin{tabular}{|c|c|c|c|c|c|c|c|c|c|c|c|}
\hline & \multirow{3}{*}{ Questions } & \multicolumn{5}{|c|}{ Frequency of Responses \%(Count) } & \multirow{3}{*}{$\begin{array}{l}\mathrm{G} \\
p\end{array}$} & \multirow{3}{*}{$\begin{array}{l}\text { A } \\
p\end{array}$} & \multirow{3}{*}{$\begin{array}{l}\mathrm{U} \\
p\end{array}$} & \multirow{3}{*}{$\begin{array}{l}\mathrm{S} \\
p\end{array}$} & \multirow{3}{*}{$\begin{array}{l}\mathrm{Y} \\
p\end{array}$} \\
\hline & & \multirow[b]{2}{*}{ 0/Day } & \multirow[b]{2}{*}{ 1-2/Day } & \multirow[b]{2}{*}{ 3-5/Day } & \multirow[b]{2}{*}{ 6-10/Day } & \multirow[b]{2}{*}{$>10 /$ Day } & & & & & \\
\hline & & & & & & & & & & & \\
\hline Q 5 & $\begin{array}{l}\text { Frequency of simple hand } \\
\text { washing before the } \\
\text { SARS-CoV-2 pandemic }\end{array}$ & $0.8(1)$ & $4.8(6)$ & $43.7(55)$ & $39.7(50)$ & $11.1(14)$ & 0.376 & 0.591 & 10.09 & 0.32 & 0.040 \\
\hline \multirow[t]{2}{*}{ Q 6} & $\begin{array}{l}\text { Frequency of simple hand } \\
\text { washing during the } \\
\text { SARS-CoV-2pandemic }\end{array}$ & 0 & $1.6(2)$ & $17.5(22)$ & $38.1(48)$ & $42.9(54)$ & 0.504 & 0.715 & 50.66 & 0.07 & 0.42 \\
\hline & & Never & Rarely & Sometimes & Often & Always & & & & & \\
\hline Q 7 & $\begin{array}{c}\text { Do you perform } \mathrm{HH} \text { before } \\
\text { and after contact with the } \\
\text { patient? }\end{array}$ & 0 & 0 & $3.2(4)$ & $0.8(1)$ & $96(121)$ & 0.84 & 0.14 & 0.25 & 0.38 & 0.37 \\
\hline Q 8 & $\begin{array}{l}\text { Do you perform HH before } \\
\text { applying gloves? }\end{array}$ & $0.8(1)$ & 0 & $7.3(11)$ & $9.3(14)$ & $82(123)$ & 0.44 & 0.41 & 0.20 & 0.01 & 0.14 \\
\hline Q9 & $\begin{array}{l}\text { Do you perform } \mathrm{HH} \text { after } \\
\text { removing gloves? }\end{array}$ & 0 & 0 & $4(5)$ & $15.9(20)$ & $80.2(101)$ & 0.09 & 0.60 & 0.20 & 0.92 & 0.17 \\
\hline $\begin{array}{l}\mathrm{Q} \\
10\end{array}$ & $\begin{array}{c}\text { Do you perform } \mathrm{HH} \text { after } \\
\text { using the toilet? }\end{array}$ & 0 & 0 & $0.7(1)$ & 0 & $96.7(145)$ & 0.85 & 0.13 & 0.14 & 0.37 & 0.38 \\
\hline $\begin{array}{c}\mathrm{Q} \\
11\end{array}$ & $\begin{array}{c}\text { Do you perform HH before } \\
\text { meal? }\end{array}$ & 0 & 0 & $3.2(4)$ & $2.4(3)$ & $94.4(119)$ & 0.95 & 0.19 & 0.14 & 0.59 & 0.04 \\
\hline $\begin{array}{l}\mathrm{Q} \\
12\end{array}$ & $\begin{array}{l}\text { Do you perform HH when } \\
\text { hands are visibly dirty? }\end{array}$ & $0.8(1)$ & 0 & $3.2(4)$ & $3.2(4)$ & $92.9(117)$ & 0.95 & 0.24 & 0.01 & 0.09 & 0.44 \\
\hline $\begin{array}{l}Q \\
13\end{array}$ & How often do you use soap? & $1.6(2)$ & $2.4(3)$ & $9.5(12)$ & $9.5(12)$ & 77(97) & 0.61 & 0.83 & 0.08 & 0.66 & 0.93 \\
\hline $\begin{array}{l}Q \\
14\end{array}$ & $\begin{array}{l}\text { How often do you use } \\
\text { antiseptique soap? }\end{array}$ & $7.9(12)$ & $20.6(26)$ & $30.2(38)$ & $24.6(31)$ & $16.7(21)$ & 0.02 & 0.23 & 0.59 & 0.70 & 0.92 \\
\hline $\begin{array}{c}\mathrm{Q} \\
15\end{array}$ & $\begin{array}{l}\text { How often do you use } \\
\text { antiseptique gel? }\end{array}$ & 0 & $6.3(8)$ & $17.5(22)$ & $36.5(46)$ & $39.7(50)$ & 0.10 & 0.26 & 0.07 & 0.29 & 0.06 \\
\hline
\end{tabular}

No statistically significant differences were found in terms of educational background or gender. Most students always perform $\mathrm{HH}$ before and after contact with the patient, before applying gloves, after removing gloves, after using the toilet, before meals, and when hands are visibly dirty (Table 2).

Statistically significant differences were found in hands washing after using the toilet by year of study, in favor of sixth-year students $(p<0.05)$ and in hand washing when hands are visibly dirty by the university attended $(p<0.05)$, with a higher percentage for students attending the university in Iasi (61.9\%) compared to those attending the UMP2 $(30.95 \%)$. Female students use antiseptic soap more often than male students $(p<0.05)$. Most students consider that simple hand decontamination can prevent the transmission of infections after contact with the patient, followed in descending order by: immediately after exposure to biological fluids (saliva, blood), after touching the areas near the patient, and 
before aseptic procedures. Although differences were found in the response rate percentage regarding infection control by hand decontamination and the frequency of solutions used, these differences were not statistically significant by gender, background, specialization, university or year of study $(p>0.05)$. A percentage of $15.9 \%$ (20) of the investigated students do not know that washing with soap and water removes organic matter and transient flora from the skin surface, and $43.7 \%$ of them (55) consider that antiseptic soap is more effective than antiseptic solutions.

The vast majority of students agree that antiseptic solutions are used when soap and water are not available and $14.3 \%$ (18) do not know that rubbing hands with antiseptic solutions reduces the resident flora on the skin surface. A considerable percentage of the students, $77 \%$ (97) use antiseptic solutions when the hands are not visibly dirty (Table 3).

Table 3. Response rate percentage regarding infection control by simple hand decontamination. Results of statistical significance tests.

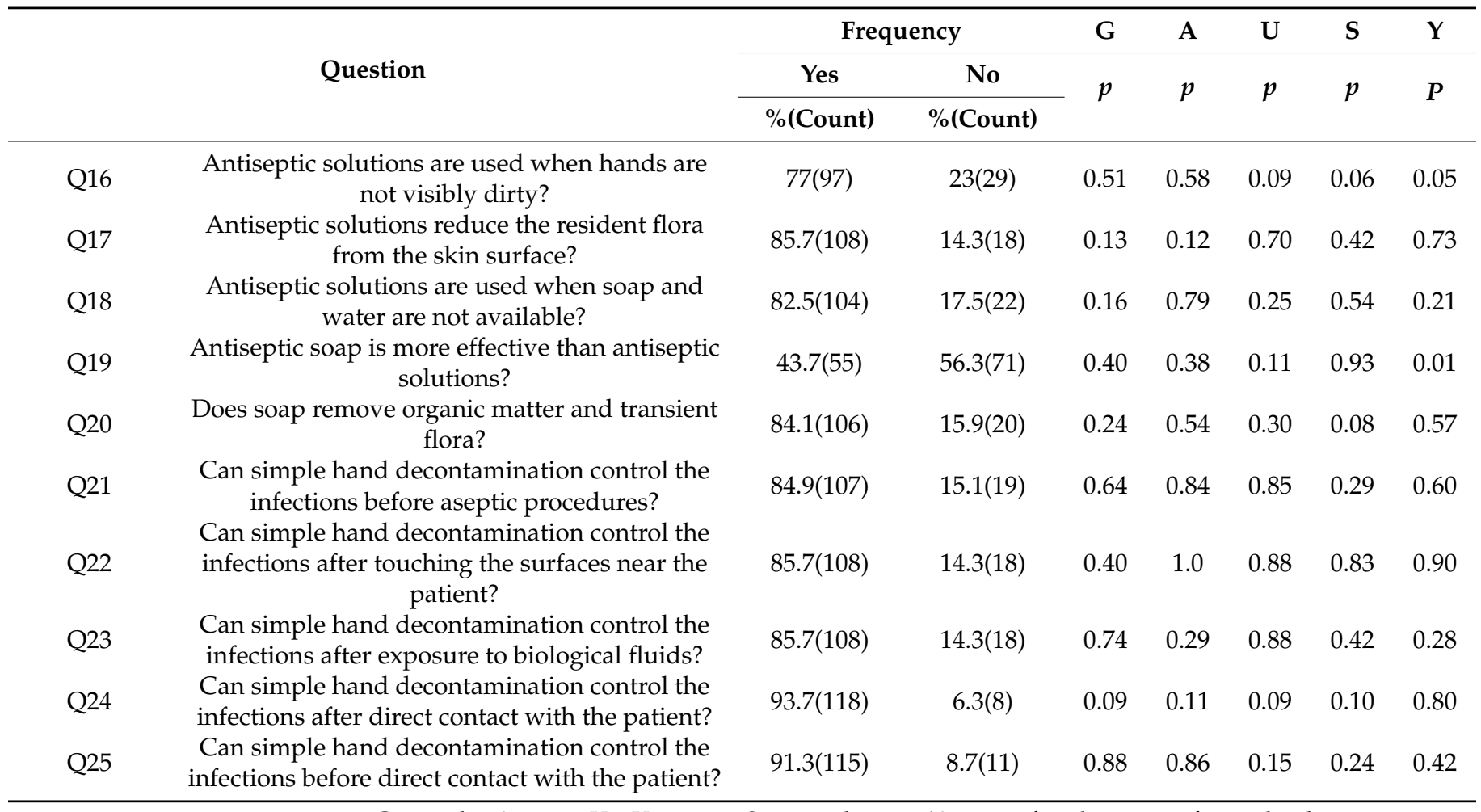

$\mathrm{G}=$ gender, $\mathrm{A}=$ area, $\mathrm{U}=$ University, $\mathrm{S}=$ specialization, $\mathrm{Y}=$ year of study, $p=$ significance level.

A percentage of $40.5 \%$ (51) of the investigated students state that they have "to a very large extent"sufficient knowledge, whereas 50.8\% (64) of them consider that they have "largely" sufficient knowledge regarding the techniques of hand decontamination. Most students claim that they know that hand decontamination is a measure to control infection. Only $48.4 \%$ of them (60) feel guilty and $44.4 \%$ (56) feel frustrated when they fail to perform proper hand hygiene. Not all students follow the recommendations of the World Health Organization guide on $\mathrm{HH}$. No significant differences were observed by gender, background, specialization, university or year of study $(p>0.05)$ (Figure 1). 


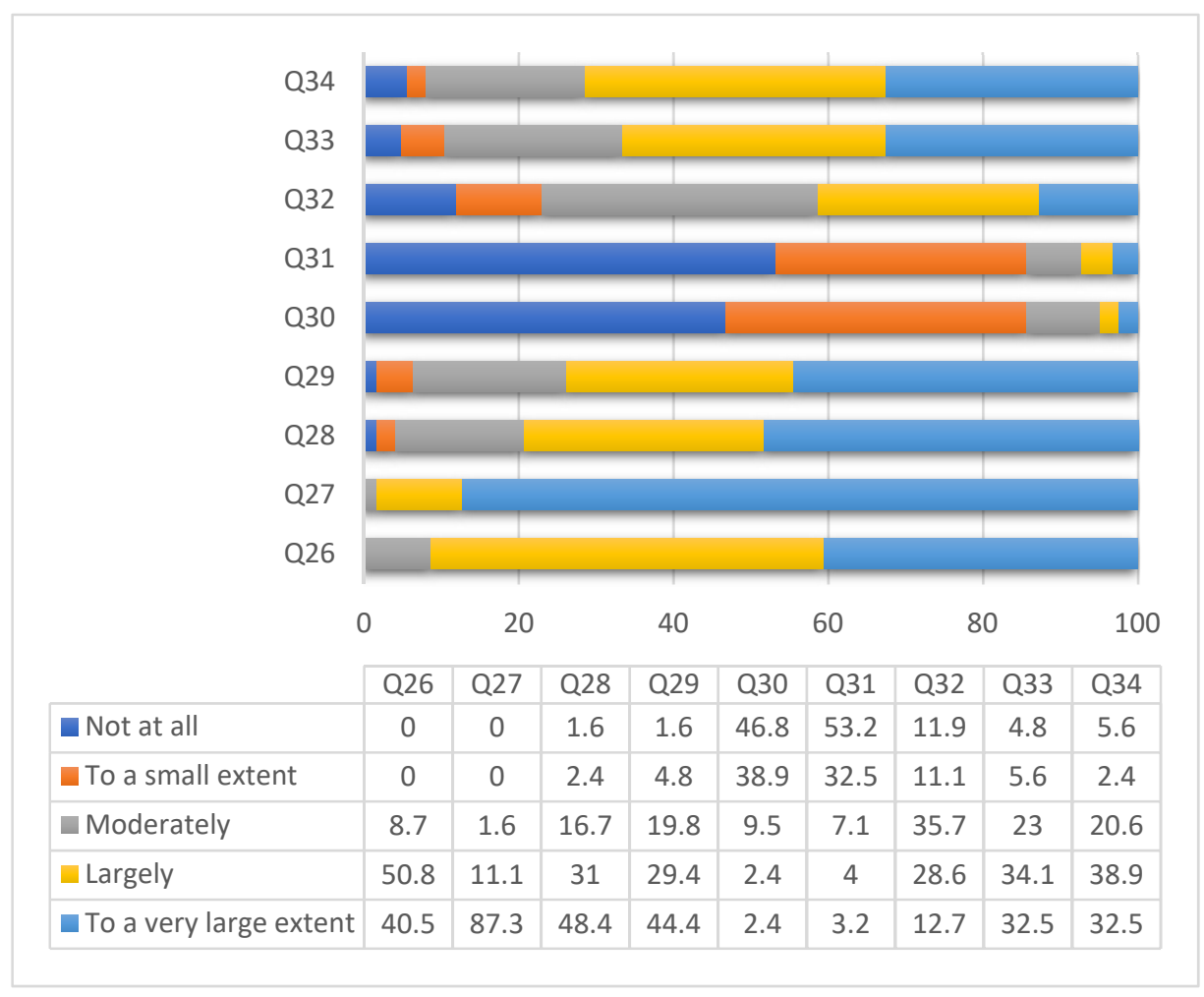

Figure 1. Distribution of answers concerning knowledge on hand decontamination. The questions were as follows: Q26 = I have sufficient knowledge of HH techniques; Q27 = I consider HH to be a measure of infection control; Q28 = When I fail to do proper HH I feel guilty; Q29 = When others omit $\mathrm{HH}$, I feel frustrated; Q30 = Sometimes I forget to make HH; Q31 = Emergencies make me not practice $\mathrm{HH}$; Q32 = Sometimes I explain to others the correct HH technique; Q33 = I use the HH technique recommended by $\mathrm{WHO}$; Q34 = I perform $\mathrm{HH}$ with antiseptic according to $\mathrm{WHO}$ recommendations.

Regarding surgical hand washing, almost all students consider the following issues to be important: removal of jewelry, watch and artificial nails, as well as shortening of nails before surgical HH. A percentage of 70.6\% (89) consider that antiseptic soap with $4 \%$ chlorhexidine (CHX) can be used for surgical washing, and 73.0\% (92) know that the hands should be kept up and the elbows should be kept down during surgical washing. A large percentage of students, $96.8 \%$ (122), know the surfaces of the hands that need to be decontaminated during surgical washing. Significant differences were found by year of study regarding the hand areas for decontamination, by year of study, specialization and gender regarding the positioning of hands and elbows, and by gender regarding forearm inclusion in surgical HH $(p<0.05)$ (Table 4$)$.

Most of the students consider that the time required to wash their hands with soap and water is of 30-60 s, and the time required to decontaminate their hands with antiseptic is $20 \mathrm{~s}$ (Table 5). The duration of surgical HH was estimated at 2-3 min or $5 \mathrm{~min}$ by approximately equal percentages of students. The concentration of ethanol in antiseptic was estimated at $70 \%$ by half of the investigated students, and the required amount of antiseptic solution to be used was estimated at $3-5 \mathrm{~mL}$ by $69.8 \%$ (88) of the students. A little more than a half of respondents consider that the residual action of antiseptics is due to CHX. For hand drying, 52.4\% (66) of students use a cotton towel and 45.2\% (57) use paper towels. The multitude of answers regarding the importance of washing hands with soap and water confirms the hypothesis. Faculty courses were the main source of information on $\mathrm{HH}$ for $65.9 \%$ (83) of the students. Significant differences $(p<0.05)$ were found in the recommended duration for $\mathrm{HH}$ by year of study, in the usual concentration of ethanol in antiseptic, in the reason for a residual action and in the method of hand drying by specialization, and in hand washing with soap and water as a habit by gender. 
Table 4. Response rate percentage regarding infection control by surgical decontamination. Results of statistical significance tests.

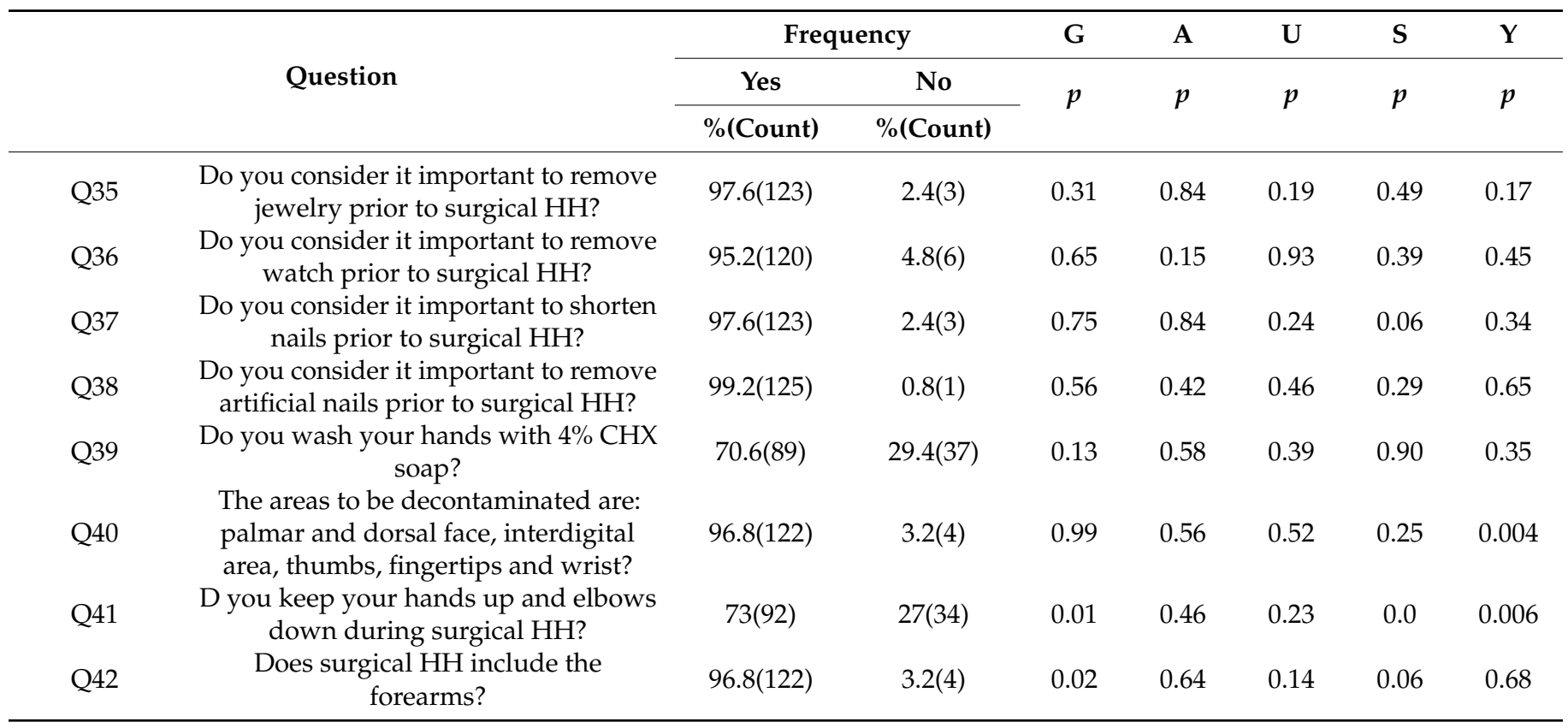

$\mathrm{G}=$ gender, $\mathrm{A}=$ area, $\mathrm{U}=$ University, $\mathrm{S}=$ specialization, $\mathrm{Y}=$ year of study, $p=$ significance level.

Table 5. Frequency of answers to questions concerning antiseptic substances for HH. Results of statistical significance tests comparing the frequency of answers on antiseptic substances for $\mathrm{HH}_{\ell}$ by variables.

\begin{tabular}{|c|c|c|c|c|c|c|c|c|c|c|c|}
\hline \multirow{2}{*}{\multicolumn{2}{|c|}{ Question }} & \multicolumn{5}{|c|}{ Interval } & \multirow{2}{*}{$\begin{array}{c}\mathrm{G} \\
p\end{array}$} & \multirow{2}{*}{$\begin{array}{l}\mathrm{A} \\
p\end{array}$} & \multirow{2}{*}{$\begin{array}{l}\mathrm{U} \\
p\end{array}$} & \multirow{2}{*}{$\begin{array}{l}\mathrm{S} \\
p\end{array}$} & \multirow{2}{*}{$\begin{array}{l}\mathrm{Y} \\
p\end{array}$} \\
\hline & & & Fre & uency \%(Cou & & & & & & & \\
\hline Q43 & The duration of HH with soap & $\begin{array}{l}10 \mathrm{~s} \\
0.8(1)\end{array}$ & $\begin{array}{c}20 \mathrm{~s} \\
38.1(48)\end{array}$ & $\begin{array}{c}30-60 \mathrm{~s} \\
54(68)\end{array}$ & $\begin{array}{c}2 \mathrm{~m} \\
7.1(9)\end{array}$ & & 0.23 & 0.82 & 0.17 & 0.11 & 0.02 \\
\hline Q44 & $\begin{array}{l}\text { The duration of HH with } \\
\text { antiseptic solution }\end{array}$ & $\begin{array}{c}10 \mathrm{~s} \\
18.3(23)\end{array}$ & $\begin{array}{c}20 \mathrm{~s} \\
63.5(80)\end{array}$ & $\begin{array}{l}30-60 \mathrm{~s} \\
18.3(23)\end{array}$ & $\begin{array}{c}2 \mathrm{~m} \\
0.0(0)\end{array}$ & & 0.62 & 0.87 & 0.28 & 0.83 & 0.05 \\
\hline Q45 & The duration of surgical $\mathrm{HH}$ & $\begin{array}{l}1-2 \mathrm{~m} \\
0.0(0)\end{array}$ & $\begin{array}{c}2-3 \mathrm{~m} \\
42.9(53)\end{array}$ & $\begin{array}{c}5 \mathrm{~m} \\
43.7(54)\end{array}$ & $\begin{array}{c}10 \mathrm{~m} \\
13.5(17)\end{array}$ & & 0.57 & 0.41 & 0.73 & 0.05 & 0.61 \\
\hline Q46 & $\begin{array}{l}\text { What is the concentration of } \\
\text { ethanol in antiseptic solutions? }\end{array}$ & $\begin{array}{l}40-60 \% \\
18.3(23)\end{array}$ & $\begin{array}{c}70 \% \\
54.8(69)\end{array}$ & $\begin{array}{r}90 \% \\
5.6(7)\end{array}$ & $\begin{array}{l}\text { I don't } \\
\text { know } \\
21.4(27)\end{array}$ & & 0.86 & 0.06 & 0.22 & 0.03 & 0.09 \\
\hline Q47 & $\begin{array}{l}\text { What is the recommended } \\
\text { amount of antiseptic? }\end{array}$ & $\begin{array}{l}1-2 \mathrm{~mL} \\
22.2(28)\end{array}$ & $\begin{array}{l}3-5 \mathrm{~mL} \\
69.8(88)\end{array}$ & $\begin{array}{c}7 \mathrm{~mL} \\
7.9(10)\end{array}$ & $\begin{array}{l}10 \mathrm{ml} \\
0.0(0)\end{array}$ & & 0.94 & 0.35 & 0.87 & 0.89 & 0.74 \\
\hline Q48 & $\begin{array}{l}\text { Antiseptics have a residual } \\
\text { action if they contain: }\end{array}$ & $\begin{array}{l}\text { Glycerin } \\
19.8(25)\end{array}$ & $\begin{array}{c}\text { CHX } \\
54(68)\end{array}$ & $\begin{array}{l}\text { Triclosan } \\
14.3(18)\end{array}$ & $\begin{array}{l}\text { Iodoform } \\
11.9(15)\end{array}$ & & 0.05 & 0.13 & 0.39 & 0.05 & 0.53 \\
\hline Q49 & $\begin{array}{l}\text { What do you use most often to } \\
\text { dry hands? }\end{array}$ & $\begin{array}{l}\text { Cotton } \\
52.4(66)\end{array}$ & $\begin{array}{c}\text { Paper } \\
45.2(57)\end{array}$ & $\begin{array}{l}\text { Gown } \\
\text { sleeve } \\
0.8(1)\end{array}$ & $\begin{array}{l}\text { Dryer } \\
1.6(2)\end{array}$ & $\begin{array}{l}\text { I don't } \\
\text { dry } \\
0.0(0)\end{array}$ & 0.79 & 0.59 & 0.16 & 0.00 & 0.90 \\
\hline Q50 & $\begin{array}{l}\text { Has washing your hands with } \\
\text { soap become a habit? }\end{array}$ & $\begin{array}{c}\text { Not at } \\
\text { all } \\
0.0(0)\end{array}$ & $\begin{array}{c}\text { To a } \\
\text { small } \\
\text { extent } \\
0.0(0)\end{array}$ & Moderately & Largely & $\begin{array}{c}\text { Very } \\
\text { largely } \\
92.1(116)\end{array}$ & 0.01 & 0.25 & 0.32 & 0.31 & 0.21 \\
\hline Q51 & $\begin{array}{c}\text { What were your sources of } \\
\text { information? }\end{array}$ & $\begin{array}{l}\text { Media } \\
17.5(22)\end{array}$ & $\begin{array}{l}\text { Faculty } \\
65.9(83)\end{array}$ & $\begin{array}{l}\text { Family } \\
10.3(13)\end{array}$ & $\begin{array}{l}\text { Friends } \\
4.8(6)\end{array}$ & $1.6(2)$ & 0.16 & 0.92 & 0.86 & 0.76 & 0.43 \\
\hline
\end{tabular}

$\mathrm{G}=$ gender, $\mathrm{A}=$ area, $\mathrm{U}=$ University, $\mathrm{S}=$ specialization, $\mathrm{Y}=$ year of study, $p=$ significance level, $\mathrm{s}=$ secondes $\mathrm{m}=$ minutes, $\mathrm{CHX}=$ Chlorhexidine

\section{Discussion}

Knowledge of $\mathrm{HH}$ infection control methods is essential for students [3,10-13,25,26]. $\mathrm{HH}$ is a routine procedure, which aims to remove organic matter and transient flora. The use of an antiseptic soap will determine, in addition to the cleansing action by the physical removal of organic matter, the inactivation of microorganisms, by the action of antiseptic 
substances in its composition [3]. The results of the present study show that the level of students' knowledge on the five moments of $\mathrm{HH}$ is high. In this study, we did not assess the level of knowledge before the onset of the SARS-CoV-2 pandemic, but the results of other studies indicate that the majority of respondents $(83 \%)$ had a high knowledge of $\mathrm{HH}$, due to the development of student training programs [27]. However, another study conducted before the onset of the SARS-CoV-2 pandemic found that only $63 \%$ of medical students included in their study knew the five moments of $\mathrm{HH}$ [28].

Another parameter considered was the duration of simple and antiseptic decontamination of the hands. Approximatively half of all respondents (54\%) know the recommended duration of 20-30 s for simple $\mathrm{HH}$ whereas $38 \%$ consider that $20 \mathrm{~s}$ is enough for complete hand cleaning. In the field of $\mathrm{HH}$, there is a European standard for the evaluation of the effectiveness of antiseptic agents for HD: EN 1499 (HH washing), EN1500 (HH rubbing) and EN12791 (surgical HH) [10]. However, many students enrolled in the present study consider that glycerin is used for its antiseptic action and, moreover, that it would have a residual action. The fact that some students consider that triclosan has remanent action and not $\mathrm{CHX}$ again indicates a low level of knowledge. Compared to simple soap, the one containing $0.3 \%$ triclosan did not lead to a significant reduction in microorganisms, except E. faecalis [10,29]. In addition, the use of triclosan is controversial because of several side effects that have been reported, such as carcinogenic effects, allergies, endocrine disorders, acute or chronic toxicity, antibiotic resistance. Therefore, in 2016, the US Food and Drug Administration banned triclosan and 17 other ingredients in antiseptic soaps, requesting more data on the efficacy and safety of these antiseptic agents [30].

A particularly important aspect is the fact that $44.7 \%$ (67) of the students do not know the action of CHX although, currently, it is considered to be the most frequently used antiseptic agent. In this context we can say that the ignorance of the advantages of using CHX implicitly attracts its non-use in practice. CHX is used in concentrations of $2 \%$ and $4 \%$ with a very wide spectrum of action and a residual action that lasts several hours [31]. $\mathrm{CHX}$ in the $0.5 \%$ concentration may increase the effectiveness of alcohol-based antiseptic. $\mathrm{CHX}$ is inactivated by anionic agents, and for this reason, it is recommended to avoid the use of creams or soaps [32,33].

The use of iodophors was indicated by only $10.7 \%$ (16) of the students. The majority of students did not know that the iodophors are antibacterial agents with a broad spectrum of activity and a prolonged action.

Alcohol is the most effective, the safest and the most widely used $\mathrm{HH}$ agent. Ethyl alcohol has a broad spectrum of activity at an increased concentration of $70-80 \%$, but with limited action in eliminating spores [10]. The effectiveness of alcohol is influenced by many factors such as: the type of alcohol used and its concentration, the contact time, the amount applied and skin moisture. In vitro studies have shown that hydroalcoholic solutions containing $60-80 \%$ alcohol have reduced bacteria by $4-\log$ to $6-\log$ in $30 \mathrm{~s}$; a shorter application time decreases the efficiency of the hydroalcoholic solution and is associated with the use of a smaller amount of product [34]. N-propanol is effective against hepatitis B virus, HIV, influenza A virus, rotavirus, adenovirus and bacteria at $60-90 \%$ concentration. $\mathrm{HH}$ with alcohol-based agents is the key measure in the prevention of healthcare-associated infections and nosocomial transmission of pathogens. A study conducted in Germany which involved dental students showed that improvements in general knowledge and special efforts were needed to increase compliance with $\mathrm{HH}$ [35].

The time required to rub hands with hydro-alcoholic solutions was known by $65.3 \%$ of students involved in this study. This result is in contrast to a study conducted in Pakistan, which reported that only $20 \%$ of respondents were aware of this issue [36]. A prospective study in an intensive-care and pediatrics unit in France showed that only a third of students knew the appropriate duration of hand rubbing before theoretical training and, furthermore, the duration of hand decontamination was found to decrease significantly during repeated procedures [37]. 
It was noteworthy that the stages of preoperative preparation of the hands were known by more than $90 \%$ of the students, and almost all respondents (97.3\%) stated that the areas that need to be decontaminated are the palmar and dorsal face of the hands, the interdigital area, the thumbs, the fingertips and the wrist. On the other hand, the answers regarding surgical $\mathrm{HH}$ technique showed that the respondents have knowledge regarding surface area: although $97.3 \%$ of them stated that surgical $\mathrm{HH}$ includes the forearms, only one third $(31.3 \%)$ had deeper knowledge of the notion of the correct position of the forearms during the preoperative preparation of the hands. $\mathrm{HH}$ is a behavioral practice, so it is important to identify the reasons for non-compliance with recommendations. In the current study, $6.7 \%$ of students answered that emergencies and other priorities make it difficult to practice $\mathrm{HH}$; however, $98.7 \%$ noted that they feel guilty when they fail to perform $\mathrm{HH}$, and $98 \%$ feel frustrated when those around them omit HH. Similar findings were found in a study conducted in India on a group of 130 students, where about $40 \%$ of medical students said that emergencies cause them to practice $\mathrm{HH}$ with difficulty and that they considered they could adhere to good $\mathrm{HH}$ practices if hygiene facilities were adequate and handy [38].

In this study, it was observed that students wash their hands more than 10 times a day after the onset of the SARS-CoV-2 pandemic. A similar result was reported by Dwipayanti et al. in Indonesia [12].

Hand drying is a routine procedure but certain aspects must be taken into account, namely: the cotton towel can be recommended but should be used only once and then reprocessed because the humid environment will favor microbial colonization; the disposable paper towel is the best option-in addition to drying, it also removes the bacteria from the skin. A hot air dryer is not recommended because it causes the aerial dissemination of microorganisms, especially when the hands are rubbed together, and, in addition, requires a longer use time of about $40 \mathrm{~s}$, produces noise, causes excessive drying of the skin and should be cleaned often [39]. Factors associated with the choice of hand-drying method include the availability of the method, the possibility of minimizing contact with the surrounding surfaces, the perception and the rapidity of the method [40]. On the other hand, there are studies showing that, instead of electric dryers, the use of paper towels reduces the spread of bacteria, recommended in hospitals or in areas at high risk of cross-contamination, [41]. In recent years, a new version of the hot air dryer has been introduced, the air-jet dryer with antibacterial filter. It has a similar efficiency to disposable wipes and requires a relatively shorter drying time compared to the hot air dryer, which helps to improve compliance. However, it has been noticed that the dispersion of bacteria in the air can reach up to $3 \mathrm{~m}$, due to the high speed of air emission during use, therefore such devices are not recommended within medical facilities [42,43].

The results of the present study show that medical and teaching staff can provide useful and complex information about hand hygiene through lectures, and they can be models for students, leading them to properly practice $\mathrm{HH}$ techniques. In addition, prevention lectures are considered to be a reliable source of information by the investigated students, a fact shown by the results of similar studies [11-14,28,36,38]. The results of the present study show that medical and teaching staff can present useful and complex information about hand hygiene in the courses and can be models for students, leading them to properly practice HD techniques. In addition, prevention lectures are considered a reliable source of information by the investigated subjects. The media also play an important role through public information programs. This study has some limitations that need to be considered: the small number of participants in this study, the distribution by gender, year of study or specialization was uneven, the subjects were randomly selected and the bias of any analyzed group was not followed.

\section{Conclusions}

Within the limits of this study, we can admit that educational measures are needed in order to guide medical staff for $100 \%$ compliance with the knowledge and adoption of $\mathrm{HH}$ measures. In order to prevent the transmission of microorganisms between patients and 
dental staff, high compliance with infection control practices is required. The study shows that most students know the moments of $\mathrm{HH}$, meaning that high compliance is needed to prevent infection control. The causes of non-compliance with hand decontamination rules are emergencies and other priorities. Most students explain, to some extent, to those around them the appropriate $\mathrm{HH}$ technique, an attitude of responsibility emphasized also by the fact that most students follow WHO recommendations. The most commonly used product for drying hands was the cotton towel (51.3\%), followed by the paper towel (44\%) and the hand dryer $(2.7 \%)$. Only $2 \%$ said they do not dry their hands. Unfortunately, half of the students use a cotton towel to dry their hands instead of a paper towel. A very small percentage of students are unaware of the disadvantages of drying their hands with a hand dryer and, therefore, use it. The most important sources of information on the correct $\mathrm{HH}$ are faculty courses and the media. The study highlights the need to improve training programs to achieve a higher level of knowledge related to hand hygiene.

Author Contributions: Conceptualization, C.I.S. and A.P.; Data curation, C.I.S., A.P. and A.E.S.; Formal analysis, C.I.S.; Investigation, A.P.; Methodology, C.I.S.; Supervision, C.I.S., D.A. and L.B.; Visualization, C.I.S., A.P., D.A., C.I. and L.B.; Writing-original draft, C.I.S., A.P. and A.E.S.; Writingreview and editing, C.I.S., D.A., C.I. and L.B. All authors have read and agreed to the published version of the manuscript.

Funding: This research received no external funding.

Institutional Review Board Statement: Ethical review and approval were waived for this study due to reason the questionnaire was uploaded to the Google docs platform. Subjects were informed that this study does not record personal data and cannot be identified. The subjects were invited to participate in research that aims to establish the level of knowledge about hand hygiene, that the research does not involve any risk, the data on the electronic devices from which they would complete the questionnaire were not highlighted in any way. It was specified that the data collected did not involve any risk and no reward would be obtained. The legislation in force regarding the ownership, use and protection of personal data-GDPR (Regulation 679/2016) has been complied with. From an ethical point of view, this study was carried out in accordance with Research Law no. 206 of 27 May 2004 on good conduct in scientific research, technological development and innovation, the Integrity Guide in Scientific Research (published by the National Council for Ethics in Scientific Research, Technological Development and Innovation on 12.11.2020) and current European legislation. Ethical acceptance for these questions was given in No. 145/31.01.2022.

Informed Consent Statement: Informed consent was obtained from all subjects involved in the study after initial information before completion and by sending the questionnaire after completion. Subjects included in the study could not be identified, therefore no written consent was required for publication.

Data Availability Statement: The data that support the findings of this study are available on request from the corresponding author.

Conflicts of Interest: The authors declare no conflict of interest.

\section{References}

1. Rotter, M. Hand washing and hand disinfection. In Hospital Epidemiology and Infection Control, 2nd ed.; Mayhall, C.G., Ed.; Lippincott Williams \& Wilkins: Philadelphia, PA, USA, 1999; Chapter 87.

2. Centers for Disease Control and Prevention: Show Me the Science-When \& How to Use Hand Sanitizer in Community Settings. Available online: https:/ / www.cdc.gov/handwashing/show-me-the-science-hand-sanitizer.html (accessed on 25 February 2021).

3. World Health Organization. Hand Hygiene-Why, How and When? 2009. Available online: https://www.who.int/gpsc/5may/ Hand_Hygiene_Why_How_and_When_Brochure.pdf (accessed on 2 March 2021).

4. Nuwagaba, J.; Rutayisire, M.; Balizzakiwa, T.; Kisengula, I.; Nagaddya, E.J.; Dave, D.A. The Era of Coronavirus: Knowledge, Attitude, Practices, and Barriers to Hand Hygiene Among Makerere University Students and Katanga Community Residents. Risk Manag. Healthc. Policy 2021, 14, 3349-3356. [CrossRef] [PubMed]

5. UNICEF. Everything You Need to Know about Washing Your Hands to Protect Against Coronavirus (COVID-19). Washing Your Hands can Protect You and Your Loved Ones. Available online: https://www.unicef.org/coronavirus/everything-you-need-knowabout-washing-your-hands-protect-against-coronavirus-COVID-19 (accessed on 3 August 2021). 
6. Ejemot-Nwadiaro, R.I.; Ehiri, J.E.; Arikpo, D.; Meremikwu, M.M.; Critchley, J.A. Hand washing promotion for preventing diarrhoea. Cochrane Database Syst. Rev. 2015, 9, 12. [CrossRef] [PubMed]

7. Curtis, V.; Cairncross, S. Effect of washing hands with soap on diarrhoea risk in the community: A systematic review. Lancet Infect. Dis. 2003, 3, 275-281. [CrossRef]

8. Stone, S.; Teare, L.; Cookson, B. Guiding hands of our teachers. Hand-hygiene Liaison Group. Lancet 2001, 357, 479-480. [CrossRef]

9. Pittet, D. Improving compliance with hand hygiene in hospitals. Infect. Control Hosp. Epidemiol. 2000, 21, 381-386. [CrossRef]

10. WHO. Clean Care is Safer Care, Clean Hands Protect Against Infection. Available online: https://www.who.int/gpsc/clean_ hands_protection/en/. (accessed on 22 December 2021).

11. Rahim, M.H.A.; Ibrahim, M.I.; Noor, S.S.M.; Fadzil, N.M. Predictors of Self-Reported Hand Hygiene Performance among Nurses at Tertiary Care Hospitals in East Coast Malaysia. Int. J. Environ. Res. Public Health 2021, 18, 409. [CrossRef]

12. Dwipayanti, N.M.U.; Lubis, D.S.; Harjana, N.P.A. Public Perception and Hand Hygiene Behavior During COVID-19 Pandemic in Indonesia. Front. Public Health 2021, 9, 621800. [CrossRef]

13. Alsoufi, A.; Alsuyihili, A.; Msherghi, A.; Elhadi, A.; Atiyah, H.; Ashini, A.; Ashwieb, A.; Ghula, M.; Ben Hasan, H.; Abudabuos, S.; et al. Impact of the COVID-19 pandemic on medical education: Medical students' knowledge, attitudes, and practices regarding electronic learning. PLoS ONE 2020, 15, e0242905. [CrossRef]

14. Lincango-Naranjo, E.; Espinoza-Suarez, N.; Solis-Pazmino, P.; Vinueza-Moreano, P.; Rodriguez-Villafuerte, S.; Lincango-Naranjo, J.; Barberis-Barcia, G.; Ruiz-Sosa, C.; Velasco, G.R.; Gravholt, D.; et al. Paradigms about the COVID-19 pandemic: Knowledge, attitudes and practices from medical students. BMC Med. Educ. 2021, 21, 128. [CrossRef]

15. Kampf, G.; Kramer, A. Epidemiologic background of hand hygiene and evaluation of the most important agents for scrubs and rubs. Clin. Microbiol. Rev. 2004, 17, 863-893. [CrossRef]

16. Pittet, D.; Dharan, S.; Touveneau, S.; Sauvan, V.; Perneger, T.V. Bacterial contamination of the hands of hospital staff during routine patient care. Arch. Intern. Med. 1999, 159, 821-826. [CrossRef] [PubMed]

17. Selwyn, S. Microbiology and ecology of human skin. Practitioner 1980, 224, 1059-1062.

18. Oughton, M.T.; Loo, V.G.; Dendukuri, N.; Fenn, S.; Libman, M.D. Hand hygiene with soap and water is superior to alcohol rub and antiseptic wipes for removal of Clostridium difficile. Infect. Control Hosp. Epidemiol. 2009, 30, 939-944. [CrossRef] [PubMed]

19. Tuladhar, E.; Hazeleger, W.C.; Koopmans, M.; Zwietering, M.H.; Duizer, E.; Beumer, R.R. Reducing viral contamination from finger pads: Handwashing is more effective than alcohol-based hand disinfectants. J. Hosp. Infect. 2015, 90, 226-234. [CrossRef] [PubMed]

20. Robinson, A.L.; Lee, H.J.; Kwon, J.; Todd, E.; Rodriguez, F.P.; Ryu, D. Adequate Hand Washing and Glove Use are Necessary to Reduce Cross-Contamination from Hands with High Bacterial Loads. J. Food Prot. 2016, 79, 304-308. [CrossRef] [PubMed]

21. Greenaway, R.E.; Ormandy, K.; Fellows, C.; Hollowood, T. Impact of hand sanitizer format (gel/foam/liquid) and dose amount on its sensory properties and acceptability for improving hand hygiene compliance. J. Hosp. Infect. 2018, 100, 195-201. [CrossRef]

22. Boyce, J.M.; Pittet, D. Guideline for Hand Hygiene in Health-Care Settings. Recommendations of the Healthcare Infection Control Practices Advisory Committee and the HICPAC/SHEA/APIC/IDSA Hand Hygiene Task Force. MMWR Recomm. Rep. 2002, 51, 1-45. [CrossRef]

23. Cheng, H.C.; Peng, B.Y.; Lin, M.L.; Chen, S.L. Hand hygiene compliance and accuracy in a university dental teaching hospital. J. Int. Med. Res. 2019, 47, 1195-1201. [CrossRef]

24. Myers, R.; Larson, E.; Bin, C.; Schwartz, A.; Da Silva, K.; Kunzel, C. Hand Hygiene Among General Practice Dentists: A Survey of Knowledge, Attitudes and Practices. JADA 2008, 139, 948-957. [CrossRef]

25. Pittet, D.; Allegranzi, B.; Sax, H.; Dharan, S.; Pessoa-Silva, C.L.; Donaldson, L.; Boyce, J.M. Evidence-based model for hand transmission during patient care and the role of improved practices. Lancet Infect. Dis. 2006, 6, 641-652. [CrossRef]

26. The Joint Commission. Measuring Hand Hygiene Adherence: Overcoming the Challenges; Joint Commission: Oakbrook Terrace, IL, USA, 2009.

27. Ekwere, T.; Okafor, I. Hand hygiene knowledge and practices among healthcare providers in a tertiary hospital, south west, Nigeria. Int. J. Infect. Control 2013, 9, 1-10. [CrossRef]

28. Van De Mortel, T.F.; Kermode, S.; Progano, T.; Sansoni, J. A comparison of the hand hygiene knowledge, beliefs and practices of Italian nursing and medical students. J. Adv. Nurs. 2012, 68, 569-579. [CrossRef] [PubMed]

29. Kim, S.A.; Rhee, M.S. Microbicidal effects of plain soap vs triclocarban-based antimicrobial soap. J. Hosp. Infect. 2016, 94, 276-280. [CrossRef] [PubMed]

30. Lin, Q.; Lim, J.; Xue, K.; Yew, P.Y.M.; Owh, C.; Chee, P.L.; Loh, X.J. Sanitizing agents for virus inactivation and disinfection. View 2020, 1, e16. [CrossRef]

31. U.S. Food\&Drug Administration. FDA issues final rule on safety and effectiveness of antibacterial soaps. In Rule Removes Triclosan and Triclocarban from over-the-counter Antibacterial Hand and Body Washes.. Available online: https://www.fda.gov/news-events / press-announcements / fda-issues-final-rule-safety-and-effectiveness-antibacterial-soaps (accessed on 20 February 2021).

32. Kaiser, N.; Klein, D.; Karanja, P.; Greten, Z.; Newman, J. Inactivation of chlorhexidine gluconate on skin by incompatible alcohol hand sanitizing gels. Am. J. Infect. Control 2009, 37, 569-573. [CrossRef]

33. Karpiński, T.M.; Szkaradkiewicz, A.K. Chlorhexidine-Pharmaco-biological activity and application. Eur. Rev. Med. Pharmacol. Sci. 2015, 19, 1321-1326. 
34. Golin, A.P.; Choi, D.; Ghahary, A. Hand sanitizers: A review of ingredients, mechanisms of action, modes of delivery, and efficacy against coronaviruses. Am. J. Infect. Control. 2020, 48, 1062-1067. [CrossRef]

35. Baier, C.; Albrecht, U.V.; Ebadi, E.; Vonberg, R.P.; Schilke, R. Knowledge about hand hygiene in the Generation Z: A questionnairebased survey among dental students, trainee nurses and medical technical assistants in training. Am. J. Infect. Control 2020, 48, 708-712. [CrossRef]

36. Naqvi, S.G.Z.; Jaffar, N.; Zehra, S.A.; Ghani, R.; Ali, H. Correlation of Hand Hygiene Knowledge and Hand Decontamination Practices of Medical Students. J. Bahria Univ. Med. Dent. Coll. 2020, 10, 147-151. [CrossRef]

37. Ghazali, A.D.; Deilhes, E.; Thomas, J.; Laland, C.; Thévenot, S.; Richer, J.P.; Oriot, D. Impact of a simulation-based training in hand hygiene with alcohol-based hand rub in emergency departments. Infect. Control Hosp. Epidemiol. 2018, 39, 1347-1352. [CrossRef] [PubMed]

38. Nawab, T.; Mehnaz, S.; Abedi, A.J.; Safwi, S.R.; Khalique, N.; Ansari, M.A.; Khan, Z. KAP study of hand hygiene among medical and nursing students in a tertiary teaching hospital. IJSAR 2015, 2, 29-39.

39. Huang, C.; Ma, W.; Stack, S. The hygienic efficacy of different hand-drying methods: A review of the evidence. Mayo Clin. Proc. 2012, 87, 791-798. [CrossRef] [PubMed]

40. Marcenac, P.; Kim, S.; Molinari, N.A. Knowledge, attitudes, and practices around hand drying in public bathrooms during the COVID-19 pandemic in the United States. Am. J. Infect. Control 2021, 49, 1186-1188. [CrossRef]

41. Kimmitt, P.T.; Redway, K.F. Evaluation of the potential for virus dispersal during hand drying: A comparison of three methods. J. Appl. Microbiol. 2016, 120, 478-486. [CrossRef]

42. Best, E.; Parnell, P.; Couturier, J. Environmental contamination by bacteria in hospital washrooms according to hand-drying method: A multi-centre study. J. Hosp. Infect. 2018, 100, 469-475. [CrossRef] [PubMed]

43. Suen, L.K.P.; Lung, V.Y.T.; Boost, M.V.; Au-Yeung, C.H.; Siu, G.K.H. Microbiological evaluation of different hand drying methods for removing bacteria from washed hands. Sci. Rep. 2019, 9, 13754. [CrossRef] 